\title{
THE RULE OF SÁNDOR PETŐFI IN THE MEMORY POLICY OF HUNGARIANS, SLOVAKS AND THE MEMBERS OF THE HUNGARIAN MINORITY GROUP IN SLOVAKIA IN THE LAST 150 YEARS
}

\author{
Gábor SCHWEITZER \\ Spoločenskovedné vúskumné \\ centrum Mad’arskej akadémie vied a Fakulta \\ verejnej správy Národnej univerzity pre \\ verejnú službu (Budapeš̌) \\ Károly VÖRÖS

Ivan HALÁSZ

Spoločenskovedné vúskumné centrum

Andor MÉSZÁROS

Mad'arskej akadémie vied (Budapeš) a Pedagogická

fakulta Univerzity Jánosa Selyeho (Komárno)

\section{ABSTRACT}

Sándor Petöfi was the greatest poet of the Hungarian romantic literature, but after his participation in the events of the Hungarian revolution of 1848 he became the legendary figure of the national liberty and republicanism. Petoff's mysterious disappearance after the battle of Segesvar further confirmed the importance of his personal heroism and at the end of the 19th Century Petöfi became an emblematic figure of the national freedom and independence not just in Hungary, but in Europe too.

Petöfi's cult was significant in the period between the two world wars too, mainly at the time of hundredth anniversary of his birth. A memorial banknote was issued on this occasion and were staged a national commemoration in 1925 .

In the communist era Petöfi was the idol of the radical revolutionary republicans, who fought against the members of the oppressive ruling classes. His glorious and heroic image became one of the figures of the Hungarian communist pantheon. But also the anti-dictatorship young intellectuals viewed Petöfi as a role model and founded Petöfi Circle prepared for the events of the revolution of 1956 .

Until the end of the seventies Petöfi became again the emblematic historical hero of the antiregime democratic opposition movement. The square at Petöfi statue was the scene of many demonstrations. This square was also the favorite commemoration place also of the Hungarian liberal political party after the Hungarian political transition in the last decade of 20th Century.

\section{KEYWORDS:}




\section{THE LIFE AND TIME OF SÁNDOR PETŐFI}

Sándor Petőfi (1st January 1823-31st July 1849) was born in a typical Hungarian agricultural town of Hungarian Lowland, in Kiskörös, in the family of István Petrovics and Mária Hrúz. However the small town, Kiskőrös had a Hungarian majority population, both of the parents of Sándor Petőfi was Slovak-speaking Lutherans. Petöfi's father consciously tried to switch to using the Hungarian language; we also have evidence of it among the documents of his preserved correspondence. Petöf's mother spoke Hungarian, although quite badly. But the Petrovics kept the family name of Slavonic origin all the time. The Hungarian-sounding version of the family name was later invented and adopted by Sándor himself. His only son was baptized to this name at the end of 1848. All the signs indicate that Petoff in his identity did not bound to the Slovak cultural and lingual heritage yet.

István Petrovics was a butcher, but through a land purchase in 1845 he gained redemptive law with collective nobility in the Jász Distrct n Kskunság. Although Petőfi was not a born Kiskun, but this probably was the origin of his sometimes appearing Kiskun identity. For instance, Petöfi referred to his Kiskun identity in the time of the election campaign in 1848. Petöfi's father wanted to educate his son in any case and because of this he sent his son to various Hungarian schools. Petöfi received his secondary education in Selmecbánya and Pápa. The latter town had a firmly multiethnic character, but this had not affected Petöfi as, it seems, in his case the Hungarian identity definitively won against the Slovak identity consciousness. For some of his school, there were conflicts even within the local Slovak milieu.

The frail and rebellious young Petöfi left the Pápa College and the whole system of education in autumn 1842 . He decided to be an artist, so first he became a trouper and then committed to be a journalist and writer. He lived for some time in the centre of the Eastern Hungarian Lowland, in Debrecen. The lowland landscape and the plains played an important role in Petöfi's poetry: for him these, and not the high places and hilly country, were the symbols of freedom.

So, the young poet departed from Debrecen to Pest in 1844, where he became the sub-editor of the Pesti Divatlap (Pest Fashion Paper). He arrived at Pest with the intention to try starting a literary career. This time Petöfi had the support of Mihály Vörösmarty, which helped him to ground his quite unstable existence in Pest. It is a fact that Petöfi had no land or any real property. Nevertheless, he found a wife from a family of lesser nobility, the rather emotional and self-conscious, emancipated Júlia Szendrey. The wife's family opposed the marriage at first, despite of Petöfi's literary fame and reputation. But it is a fact too that the Szendrey family had no possessions 
either and was situated in the manorial private service. The wife of Ignác Szendrey was a burgeois girl. But Júlia's father has agreed to the marriage in the end.

During his years in Pest, Petöfi became more and more active in the public life. He joined several associations, the Tízek Társasága (Association of the Tens), then the Fiatal Magyarország (Young Hungary), the Ellenzéki Kör (Opposition Circle), and then became the editor of the journal Életképek (Genre Pictures).

The hard-working Petöfi was able to gain regular income from his literary activity but unable to become a rich man. It is true, however, that he had no time for this either, because the revolution broke out in spring 1848, and we can say that one of the main actors of the revolution was Petoff together with his associates from the Coffee House Pilvax. At this time he wrote his poem National Song, which is one of the most important revolutionary Hungarian literary works with a strong mobilizing power until today. In the eventful year 1848, Petöfi belonged to the Pest radicals $\mathrm{He}$ first tried to get to the new, freely elected and public representative parliament in the parliament elections, but his effort was unsuccessful. At this time Petöfi wrote his antimonarchical poems too, having joined the followers of the republic. It was not surprising in the case of the romantic poet aspiring to civil independence and intellectual autonomy, mainly at the time of the revolution.

Under the influence of the election failure and the other political developments in 1848 , he became interested in a military officer career. Petőfi was a soldier in his youth, he served as a private in the 48th Imperial and Royal Infantry Regiment in 1839-1841, but was discharged due to his general bodily weakness. In the revolutionary months, Petöfi at first became a member of the Committee for the Pest City Order and the Committee of the Civil Courage of Pest County, and then he entered the militia of City of Pest as well. Petöfi became the captain of the 28th Honvéd Battalion on 15th October 1848. In January 1849 Petoffi got to the Transylvanian army and became the adjutant of general József Bem. He served as a messenger until he quarrelled with the Minister of War, Lázár Mészáros and resigned from his post. He rejoined Bem in March and took part in battles too, becoming a captain, then an adjutant again, and a major in May. But he quarrelled with the superior authorities again (namely with Deputy Minister of War György Klapka) and resigned his commission again. Moreover, Klapka also put him under a house arrest for some time. He went to Transylvania again in July 1849, where joined Bem's army. Even though Bem forbade him to join the army departing to Segesvár, Petöfi took part in the battle near Segesvár on 31th July, where was killed in action. His body was not found, which gave rise to speculation. There are still enthusiastic researchers and amateurs looking for his body. 


\section{INTRODUCTION}

The modern Hungarian history has generated several such integrative historical personalities, which is easy to interpret from the perspective of the memory policy. This was particularly true in the first part of the 19th Century. The first part of this historical age is called the reform era (1832-1847) ${ }^{1}$, and in the second part of this period there was the age of the Hungarian revolution and war for independence in 1848 and 1849. It is one of the most determinative periods of the Hungarian historical common knowledge. This is very important, because the above mentioned war for independence would be considered the first such historical event in the Hungarian history, which intensively mobilized real masses of the Hungarian society. In this period the deep rooted new type - modern or modernized - Hungarian national identity formed, which spread in the whole Hungarian society. ${ }^{2}$ A very important role in this process belonged to the cult of such personalities was Lajos Kossuth, István Széchenyi, or Sándor Petőfi.

This is related not only to their personalities and historical or artistic performance, which for many reasons was suitable for the cult building, but also that in this historical period many leading political person could fortunately combine the desire for independence and the thought of the social and national solidarity and the general - so called universal - love of freedom. We can find in this matter the reason of the still active popularity of these personalities from the first half of the 19th Century. Compared to the 20th Century, the contrast is very spectacular. Namely the quite complex and turbulent Hungarian 20th century had no such luck, since in this period often saw a sharp, almost unresolvable conflict between the human rights and

${ }^{1}$ This name is connected to the reform-style parliaments of this period. The feudal diets had an important role in the preparation of the bourgeois reforms because of the specificity of the Hungarian public law system. On these Diets also the feudal Hungarian liberal opposition was formed, which got to the determinative position in 1848 .

${ }^{2}$ This idea is based mainly on the theory of the Czech historian, Miroslav Hroch, who thoroughly examined the genesis and dynamics of the Central and Eastern European national movements at the end of the 18th and at the beginning of the 19th Century. According to the Hroch's theory almost every national movement of the region went through three similar phases. The first phase, which almost everywhere took place at the end of the 18th Century, begot the interest of the enlightened urban bourgeoisie towards the rural population. This interest also involved ethnographical items. Many language codification attempts took place in this period. The second phase, which can be called the national agitation period, took the first decades of the 19th Century. In these decades, smaller or bigger groups of the intelligentsia with a new or renewed national identity tried to pass theirs newly discovered and experienced identity to the wider layers of the society. The new identity in this period cannot always be considered as extended to the entire society and fully accepted, since different, mostly with older origin, parallel and alternative identities still strongly held themselves. Those for whom the new type of the national identity could become a mass identity mostly had a greater and dramatically intense historical event. This could be a defence war, revolution, uprising, independence war, or a bigger opposition demonstration. In the Hungarian case there every indication that such events were the revolution and independence war of 1848 and 1849. 
the ideas of the civic freedom, the endeavour for the social solidarity and the thoughts of the intensifying nationalism.

We probably should look for the reason of the extreme popularity of the Hungarian heroic pantheon of the 19th Century in the contemporary events in the Hungarian public life. These are still very important landmarks for the Hungarian political community and public knowledge. It is also true that the periodical reinterpretation and different exposure in different ages of these elements of the national memory are not unusual.

The fact that these 1848 events reached such an outstanding rule in the Hungarian public thinking well indicates the question of the state and national holidays. Among the three nominated national holidays, the 15th March, which commemorates the 1848 revolution, is the most popular and unanimous. It is true that 20th August, which commemorates on the foundation of state by St Stephen, does not generate deep political debates, but this day is at the time of the summer vacation (for most of Budapest residents this holyday ends the summer time) and for the main part of the public opinion this day is more a family holiday than one with an actual political meaning. The foundation of the Hungarian state took place a very long time ago. Also the new layers of 20th August, created by the communist ideology: the day of the 1949 constitution and the holiday of the new bread of the year, have not became quite deep and were not even very irritating (Constitution Day, New Bread Holiday)

The third greater state (i.e. neither religious nor family) holiday in Hungary is also connected to a revolution and war for independence, namely the anti-Stalinist uprising in 1956, which the Hungarian people and the Hungarian political community officially commemorate since 1989, always on 23rd October. The events of 1956 still have a lot of witnesses, since there were not so long ago, and because of this the current political crosstalk of this holyday is stronger than the others. This problem does not exist in the case of 15th March.

It is well known that one of the key players of 15 th March 1848 was young Sándor Petöfi and his company formed around the Pilvax Caffé, which he also often visited. Because of this, no present-day celebration of this day is possible without the renovation and utilization of the cult of Petöfi. Not just his personality, but his poems are inseparably connected with this day. Strictly speaking, the hero of this day "technically" is the poet Petőfi himself and not Lajos Kossuth or István Széchenyi who were somewhat older and more influential than him. The names of the above-mentioned politicians are connected more to the reform age and the war for the Hungarian independence than the events of 15th March. 


\section{WHY EXACTLY SÁNDOR PETÖFI?}

The personality of the poet-revolutionary Sándor Petőfi firmly exceeded from the many famous person of the first half of the 19th Century. It has had many reasons. The first one has already been mentioned: one of the main actors and organisers of the revolutionary events on 15 th March was the ardent young poet with a plebeian origin. The poem National Song (Nemzeti dal) written by him in the days of the revolution is one of the basic literary works of the Hungarian patriotism and love of the freedom until today. No wonder that this poem is still accepted as one of the most popular mobilizing text of the democratic and patriotic movements and demonstrations. ${ }^{3}$

Petöfi was not just a romantic poet frequently encouraging to action, he also lived as befits a romantic hero. Despite his poor health he was an unruly pupil, then a poor strolling player, radical political journalist, and afterwards a revolutionary popular tribune and the officer of the independence army, and at the end he failed as the hero of the freedom war, whose dead body has never been found, because of which many people are still looking for him. Thus it is still believed that Petöfi did not die in the battle in Transylvania near the town of Segesvár, but the intervening Russian army troops dragged him to Russia, where he died just years later. A whole Hungarian discovery mission searched the poet's tomb and remains in the Russian town Barghuzin at the turn of the 1990s. This mission was supported by a rich Hungarian entrepreneur, Ferenc Morvai. The mission made some findings, but the descendants of collateral relatives of Sándor Petőfi did not allow the exhumation of the Petőfi ancestors or the DNA analysis of theirs bones; it is still not proven beyond doubt that Petöfi's remains were foundd by the researchers at that time or rather someone else's.

Therefore, the life and death of Sándor Petöfi are surrounded by many legends. He married at a young age to the great love of his life, Júlia Szendrey. Everybody expected that after Petőfi's unexpected death Júlia Szendrey would become the "widow of the nation", but she did not. Petöfi is regarded as a Hungarian romantic poet, but he had no Hungarian origins (though he had a strong Hungarian identity). Petöfi was born as Alexander Petrovics in Kiskörös, but there is a lot of uncertainty around the place and time of his birth. The question of Petöfi's origin is even more exciting. There is a version, according which his father was a butcher and innkeeper of Serbian origin and his mother, Mária Hrúzová, was a Slovak woman. But the truth is rather that his both parents were Slovak Lutherans from the southern Hungarian Lowland, as wasthe whole neighbourhood where he grew up.

\footnotetext{
${ }^{3}$ This poem played a very important role also at the time of the 1956 revolution and the 1989 demonstrations.
} 
Petöfi carried out all his school in Hungarian. Otherwise, as a native of the Great Hungarian Lowland, he never wrote about mountains, which never symbolized the freedom and the passion for him, as for many other romantic writers and poets. The symbols of freedom for him were rather the plain and the puszta. His Slovak origin hardly played a role in his art - Petöfi wanted to be a Hungarian poet and he did it so. Petőfi's becoming a Hungarian and his whole political and social life well symbolised and illustrated the assimilation power of the Hungarian national idea and culture in 19th Century. Petöfi was not alone in this romantic age - Mihály Táncsics, with Serbian origin, was one of the most consistent representatives of the social idea and freedom of press in 1848, and the German-speaking Ferenc Liszt became the face of the Hungarian music at European level. For the Slovak national movement, Petöf for a long time remained an "assimilated", who served the cultural life of an other - not the native - nation, which was greatly depressing to the Slovaks. The fact that Petöfi was born in the south, on the so called "Slovak island in the Hungarian sea", facilitated the acceptance of it.

This above-mentioned contradiction of origin and ethnicity is a priori interesting from the viewpoint of memory policy. But there are more tensions in Petöfi's life, his art and political heritage, which are serious tasks for the experts on the memory policy of later ages and all kinds of ideologies. The vast majority of the leaders of the generation of the Hungarian reformers and freedom fighters had a gentry or aristocratic origin, and because of this the plebeian Petöfi (and the above-mentioned Táncsics too) slightly stick out of the series of main characters. Although the Hungarian revolution and independent war managed to dethrone the Habsburgs in April 1849, but among the emblematic public figures a few still demanded the hanging of kings, and so did the republican Petöfi in a poem at that time. This "verbal excursion" caused problems for the official experts of the memory policy not just in the age of consolidation of natural dualism, but also in the ultraconservative interwar age of Horthy, but it became popular, of course, after 1945.

Though Petőfi's anti-monarchical position, republican and plebeian attitude was likeable for communist ideologists after 1945, or rather after 1948, his strong national commitment, desire for independence, and love of freedom could cause problems. Not to mention the circumstances of his death, as Petöfi died in a battle against the Russians. These are the aspects, because we chose the Hungarian poet of 19th Century in the frame of the project. But let us see the whole memory policy process in detail. 


\section{THE BEGINNING OF THE PETÖFI CULT IN THE SECOND PART OF THE 19TH CENTURY AND IN THE TURN OF THE 19TH AND 20TH CENTURIES}

Sándor Petöfi, after 15th March 1848, after his action in the events of the Hungarian revolution in Pest, was not primarily known as a poet. His role in the revolution was more than just a part of his literary oeuvre, it meant the start of the cult of the most popular Hungarian poet and literate. As one of the leaders of the revolutionary movement, the leader of the so-called March-youths, he became very popular and not just within the borders of the Hungarian state. Though his poems, which had anti-monarchical or republican contents, almost shocked his contemporaries and the poet at the time of the war for the independence in 1848 and 1849 received less attention, but the most important events of his life (his election failure and military service) always were the main topic of the Hungarian press, mainly of the newspaper of the radical wing of the revolution movement Marczius Tizenötödike (15th March).

The disappearance of Petöfi on the battlefield had a lot of interpretations; many people explained that Petöfi had fled abroad. Because of this an imperial command was issued for his interception and the published new volume of Petöfi's poems was confiscated in 1851 too. Petöfi's wife, Júlia Szendrey, after a lengthy investigation, issued an official notice on 21 July 1850 . According to this document her husband could be declared dead, because he was "murdered in the Transylvanian battle". Júlia, the "wife of all wives" quickly remarried, which outraged not just Petöfi's admirers but also his friends, like the poet János Arany, who was known of his legendary tolerance. The general public could not reconcile with the loss very long. In the whole country there appeared a lot of frauds and pseudo-Petofis. To act as the famous, disappeared poet was calculated as a good profitable profession for a very long time.

When there was no more hope, Sándor Petőfi became the one of the most important martyr of the revolution and war for the independence in 1848 and 1849. Petöfi, along with the executed Hungarian Prime Minister Lajos Batthyány and the martyrs of Arad, got a prestigious place in the national legendary. The object of his cult were his whole life and also his poetry, mostly his prophetic poems in which he foresaw his early and sudden death. For Hungarians Petöfi meant the phenomenon of the national poet all in capital letters already from the 50's of the 19th Century. As László Németh, the opinion leader Hungarian essayist of the 20th Century wrote in the interwar period, Petöfi is the greatest light of the Hungarian literature. Németh wrote that the Hungarians can see their whole national literature in his light, and the light of Petöfi's works makes false not just the works of the literary generation 
of posterities but also the ancestors. Petöfi's works made something more from the works of his ancestors - Petöfi's oeuvre. Petöfi is such a great relic of the Hungarian literature and Hungarian spirit that nobody can disbranch him. Petófi's poetry was the wedding time of the Hungarian poetry, the times before were its girlhood and after its.

After Petőfi's death, a lot of Petöf's epigones appearedin the Hungarian literature, the most famous anibg whom wa Kálmán Lisznyai, who propagated the so called palóc dialect and wrote on some ancient Hungarian mythology, mainly based on the old Slovakian people legends of the region. The administration of the neo-absolutist era of Alexander Bach very actively propagated his popular echo poetry in order to get support among the members of the lower social strata.

It well demonstrates the absurd situation in the literary life of the 1850s that those who criticized the overstatements of the Petöfi's epigones accused him of unpatriotism. According to János Arany, who was also one of the teachers of Sándor Petöfi, in this period the Petöfi's shadow was already cast on the whole Hungarian literature, and this fact inhibited its further development.

There were also some positive effects of this early cult of the poet, on the one hand the translation activity got a great impulse, thanks to which those who were the exemplars for Petöfi at the time he wrote his poetry, such as Heine and Béranger, could now read his poems. Béranger spoke appreciatively on Petőfi's poetry, Heine ironically but appreciatively that Petöfi is a healthy and primitive poet, and Nietsche, who was a great admirer of the Hungarian revolution, composed a piece of music for Petöfi's poems. Petöfi increasingly became the poet of the freedom of nations and from the end of the 1850s had already been the primary representative of the Hungarian literature abroad.

In the age of dualism the public still admitted Petöfi's role in the events of the revolution, but in the history of Hungarian literature a tradition was built that what was most important in Petöfi's poetry was just the tendency for the popular tone, and his prophetic, pessimistic political poetry already became less important parts of his oeuvre.

The authors of the literary history of positivism misjudged political poems in Petöfi's works. They said that beside the landscape depiction and popular character of his poetry, these poems are secondary, moreover also false.

The official Petöfi's cult was built in the middle of the 1860s, when the Petöfi Association (Petöfi Társaság) was established for the cultivation of the tradition of the greatest Hungarian poet. The association, which was the circle of the conservative literary trend representatives (the association of the younger literates was the Kisfaludy Association, or Kisfaludy Társaság), collected Petőfi's manuscripts, docu- 
ments. The Petöfi Association founded a Petöfi Museum, which was the antecedent of the present Museum of the Hungarian Literature and published volumes of the series Petöfi's Library.

The generation of the literary journal Nyugat (West) at the beginning of the 20 th Century already did not have a clear opinion on Petöfi's cult. One representative of the trend was Endre Ady, who saw Petöfi as his ancestor. According to his opinion Petöfi was a radical and solitary perspicacious poet, seeing the fate of his land, and was more than a simple poet of people-tone poetry. Mihály Babits had a different opinion, first contrasting Petöfi with János Arany and formulating his famous and important statement, which is still one of the most popular thoughts on Petoffi's poetry. Babits said that "Petöfi is a petty bourgeois in the mask of a genius and Arany is a genius in the mask of a petty bourgeois", and with this idea Babits started the modern revision of Petöfi's cult.

We can consider that the most important elements of Petöfi's cult from the 19th Century are his role of the representative of the Hungarian literature abroad, the poet of the national freedom, and the naivety and people tone of his poetry. Petófi's cult was already an independent capitol of the Hungarian cultural history at the end of the first decade of the 20th Century.

\section{REFLECTIONS ON THE HISTORY OF PETÖFI'S CULT IN THE INTERWAR PERIOD}

Sándor Petőfi a high-spirited poet, a revolutionary democrat, who sympathized with the republican ideas, the bard of the world freedom; he belonged to the martyrs of the bourgeois revolution and the anti-Habsburg Independence War of 1848 and 1849. After his death several political movements and political systems set his name to its flag. Because of this we can regard Sándor Petöfi, who became become a national public body, the "charismatic patron saint" of the Hungarian policy-making.

In the wake of the defeat in World War I and the fall of the bourgeois democratic and social revolutions in 1918 and 1919, a national conservative or national Christian self-oriented political force came to power in Hungary for a quarter of a century. In its ideology, this political course negated the liberal and democratic values because they believed that these values contributed to the defeat in the world war, the disintegration of the historic Hungarian state, and the revolutions that afflicted the country.

In this ideological and political force field, the celebration of the 100th anniversary of the birth of the revolutionary democrat Sándor Petőfi, who sympathized with the republican ideas, became more and more actual. Also, the national conservative politi- 
cal course wanted to take part in the celebration. For this, they had to find ideological handrails. In this spirit they strived to transform and reinterpret the political views and political poetry of Sándor Petőfi. They presented the world revolutionary Petöfi as a national revolutionary, the hero of the anti-Habsburg freedom war, as a freedom fighter struggling for the integration of the Hungarian state territory. In the general meeting of the prestigious Hungarian Historic Association (Magyar Történeti Társulat) celebrating Sándor Petőfi in 1922, the Minister of Culture Kunó Klabelsberg stressed that although Sándor Petőfi was a revolutionary, he was a "national revolutionary" whose patriotic poetry was based on the beauty and greatness of the national past. According to the findings of his other colleague, the literary historic Zoltán Ferenczi, Sándor Petöfi was not a cosmopolitan poet but a patriot, who moreover was the "apostle of nationalism".

They wanted to deaden the republican views of Sándor Petöfi and also the edge of his "king hanging" poems, written in his revolutionary vehemence, because they had to consider that the form of government of the interwar Hungary remained a monarchy, even if the throne was left vacant. János Horváth, a professor of the Budapest University, in his monograph published in the year of Petőfi's centenary, characterized Petöfi's poem "Hang up kings" written in the fall of 1848 as a masterfully demagogic rhetoric work, which could even be a part of a work by Shakespeare. According to the findings of János Horváth, Petőfi's revolutionary appearances were inspirited by Paris revolutionary norms.

For the national conservative course, which regarded itself as the exclusive depository of the national commitment, it was also extremely important to stress the poet's Magyarhood or becoming a Magyar, since he was born to Serbian and Slovak parents, which for Petöfi of course had never been in doubt. The official literates and culture-politics of the age, as Ferenc Herczeg and Jenő Rákosi, stressed the Slavic roots of the most faithful poet of the Hungarians, because they wanted to demonstrate the assimilating force of the Hungarian "race". Similar views were reflected in the essay written for the Petoffi centenary by one of the leading historians of the age, Gyula Szekfü, who presented Petöfi's poetry as the burning lyra from the "love of the Hungarian race", but he never denied the liberal-radical historical approach, revolutionary and republican views of the poet. According to the evaluation of Gyula Szekfü, nobody has to abstain from the revolutionary world of Sándor Petöfi nor from its exclusive national aspect, because we Hungarians can also be proud of the poet who, while he "wrote the most beautiful anthems of the world solidarity of the slave peoples striving for freedom," laid down his young life for the "territorial integrity" of his Hungarian homeland. 
The national and cultural assimilation of Sándor Petöfi was on the agenda one and a half decades later as well. The literary historian, Director of the Hungarian Cultural Institute in Berlin Gyula Farkas published his book The period of the assimilation in the Hungarian literature triggering a great debate, in which he received muchscepticism regarding the possibility of the assimilation for listing the case of Sándor Petöfi as a rare exception. "In the Hungarian Land and perhaps just here could happen the miracle that the son of István Petrovics and Mária Hruz - could become Sándor Petöfi." However, Petöfi was a "national poet", who even exploded the more and more choking ring of the national isolation. With his work the Hungarian intellectual spirit became a part of the "higher spiritual community" again, the members of which are Plato, Dante, Sophocles, Shakespeare, Horace, and Goethe.

On the occasion of the centenary of the birth of Sándor Petöfi in December 1922, Kunó Klebelsberg, Minister of Religion and Public Education presented a short bill to the Hungarian National Assembly on the enactment of the memory of the poet. According to this draft law, the nation remembers with gratitude Sándor Petöfi, who served with "his poetic genius" the "Hungarian national idea" and with his life and death provided an eternal example of the patriotism ready for any sacrifice. The parliament wanted to codify the memory of Sándor Petöfi referring to his merits in the home service. Among other things, the reasons of the bill pointed to the thing that ranks among the noble traditions of the Hungarian parliament: to immortalize by adopting a law the great moments of the nation's life and the memory of the great sons of the nation. The parliament has done so, when on the 40th anniversary of the crowning of Franz Joseph the grateful nation remembered it in an act from 1907. According to the reasons of the bill, the poetry of Sándor Petöfi was a part of the most characteristic, most artistic, and noble manifestations of the "thousands of years of spiritual life of Magyars". But he served the "Hungarian national idea" with his poetic genius and he remained with his life and death the eternal example the self-sacrificing love of homeland.

Sándor Petőfi evidently could be a part of the conservative national canon with the codification of this bill. A piquant situation might occur, as the poet Sándor Petöfi, servant member of the Hungarian Honvéd army fighting against the Habsburgs in 1848 and 1849, could get a similar memory bill as was slightly earlier given to the emperor Franz Joseph, who drowned the revolution in blood. According to the original ideas, the Hungarian parliament would codify the Petöfi Memorial Act on the 75th anniversary of the outbreak of the civic revolution of 1848 on 15th March 1923. But the conflicts between the government and the democratic opposition did not allow 
the Memorial Act to be passed. Although the tried opposition many times to gain acceptance for it, but the government refused it. Therefore, Petöfi's canonisation failed. But the official and non-official celebrations and commemorations were held. The Petöfi Association, established in 1876, which had the leading role in the care of the Petőfi cult, had a celebratory assembly with the presence of the governor Miklós Horthy. Also with the presence of the head of state, the poet was celebrated in the Parliament building and in the Budapest city hall. The whole country was burning with a festive fever. Only one fly in the ointment remained at the time of the celebrations, the failed Memorial Act. The dishonesty and Janus face of the official Petöfi cult were revealed by the first verse of the poem of Gyula Juhász "Petőfis centenary": "They cite his name, but his spirit not."

In any case, the representatives of the distant political sides mutually sought to monopolize the Petöfi cult. It is attested by the essay of the literary historian Bernát Alexander from the time of the centenary of Sándor Petöfi. "The socialists and the antisocialist both marched today in front of his statue erected in the Budapest Danube Promenade, the rhetoric pose of which magically attracts the demonstrators".

Two years after the Petöfi centenary, in the fall of 1925, a group of liberal and civic democrat members of parliament presented a bill to the national assembly for codifying Petöfi's memory. Their proposal was conceptually similar to the bill proposed by the Ministry of Culture years ago. This liberal-democratic proposal was unsuccessful either.

We cannot refer to the reparation of the missed canonisation, but the Hungarian National Bank issued a 50 Pengő banknote with the portrait of Sándor Petőfi in 1932. This banknote remained in circulation until 1946. In next year 1947, another banknote was issued decorated with a portrait of Sándor Petőfi in amount of 10 Forints. They, on the one hand, ensured the continuity and, on the other, confirmed the fact that every political system in Hungary created its picture of Petöfi or sought to create its own Petőfi cult.

The democratic opposition movements in the interwar period relied heavily on the Petöfi cult. A good example of it was the establishment of the Hungarian Historical Memorial Committee (Magyar Történelmi Emlékbizottság) in 1942. The worthy formal aim of the Memorial Committee was the preparation of the celebration of the centenary of the bourgeois revolution of 1848 , but in fact the Committee worked as an antifascist and anti-war forum for the national independence policy. The Memorial Committee planned a Petőfi badge, by the sculptor Pál Pátzay, which could be pinned on the coat lapel. In this way Petöfi became a symbol of the Hungarian resistance. The 
poem by Salamon Ferenc: "March is shouting" drew attention to the importance of the Petöfi badge:

Set on the badge, Petöfi's picture!

It must be a sign that something is alive and moving.

Because he is not the past, but he is the future,

And you are carrying the future now!

On the anniversary of the bourgeois revolution of 1848, on 15th March 1942, the Hungarian Historical Memorial Committee held a very memorable anti-war demonstration in front of the Budapest Petöfi statue in the attendance of thousands of people. After this demonstration, the government banned the Memorial Committee.

\section{"OUR FLAG, PETŐFI". THE PETŐFI CULT IN THE 1950s}

After the Second World War the figure of Sándor Petőfi almost immediately became the central piece of the memory policy of the Hungarian Communist Party. And it was not incidental. The propaganda machine of the contra-revolutionary system in the Horthy age consistently expressed the accusation of anti-nationalism against the left political movements. The leaders of the Hungarian Communist Party returned from Moscow struggled with the overwhelming lack of legitimacy. Because of this the Hungarian communists made great efforts to increase their social acceptance with the conscious utilization of some elements of the national history. The Rákosi system represented itself as the organic and necessary continuation of the national traditions. It created the phenomenon of progressive traditions. The Marxist historiography carefully selected from the past these events or persons about whom their historical approach based on the phenomenon of the class struggle claimed that they contributed to the necessary proceeding of humanity towards the communism. The soviet state already from the beginning worked out a universal identity for the future, but from the 1930s this system also strongly used the traditions of the Russian nationalism, providing examples for the Hungarian communists too. The Marxist historiography also stamped its mark on the Hungarian independence movements. The fights of the kurucs (Antihabsburgians) and labancs (loyalists), the tradition of 1848 came quite into view in the general anti-German mood after the Second World War, and these topics were popular in the public opinion too. This historical approach was codified by Aladár Mód in his book 400-years fight for the independent Hungary, which guided the riders by the hand from the uprising of György Dózsa until the age of Mátyás Rákosi. 
The personality of the revolutionary poet Sándor Petöfi, with his plebeian origin, his articulate (at least seemingly) poetic style, his role in the revolution of 1848 seemed to be suitable in all respects for the memory policy role the Party assigned him, so they began forming the universal icon of the ardent, utterly committed revolutionary poet. In fact, the whole process started before 1945. Also the leader of the short-lived Hungarian Soviet Republic of 1919, Béla Kun wrote a study on Petöfi and the Popular Front organized a huge anti-war demonstration near the Budapest statue of Sándor Petöfi on 15th March 1942. After the war, the Soviet side also received a green light to make a socialist icon from Petöfi: Lunarceskij said that Petőfi was a Bolshevik of his age. The communists, besides Petőfi, also underlined Endre Ady and Atilla József from the Hungarian literature, but Petöfi, because of the mentioned reasons, met the aims of the party better than the other members of this pantheon. József Révai explained it in the following manner: "It could disturb our progress, had we not related critically to such giants of the Hungarian culture as Béla Bartók, Endre Ady, Gyula Derkovits and also a part of the works of Attila József should be listed here in a manner. Theirs is a great work, eternal treasure of the Hungarian culture. But it is not a coincidence that the Hungarian poetry did not depend on the ways of Endre Ady or Attila József, but in the imaging methods and democratization of the style going back to Sándor Petöfi. These great rebels without exception had the weakness that although they hated the old world and wanted the new one, they were more or less isolated from the revolutionary popular movements of their age, or they did not quite uphold it”. Révai prominently highlights Petőfis democratic style (clarity) and his inseparability from the revolutionary movement. This was already obvious at the 100th anniversary of the death of the poet. At this event Márton Horváth gave a lecture titled "Our flag is Petöfi". In his lecture he set the poet as an example for every Hungarian writer. "The present Hungarian writer, for whom in literary sense the flag is not Petöfi makes away from the people or confronted with the people. (...) There are those who worry about their personality and the integrity or freedom of their works from the politics, the agitation, or the party claims. They are real individualities, who are willing to accept as model or high level art the verse goes shepherd on the donkey. But if this shepherd becomes for example a solder and he fights and calls for battle, if not the sorrow of love consumes him, but the troubles of his class, according to them this is already politics mixed with poetry, agitation, and an outrage against the art. (...) They besiege the political activity of masses with the arrows poisoned by lie of the password of the artistic freedom."

One of the diary notes of Gyula Illyés evoked this atmosphere: "I see from the look of the people, what a horse got or is under me: where I could canter up, if I release 
the reins too little. Yesterday S. gave me a booklet published in hundreds of thousands of copies: Révai at the National Assembley mentioned my name together with Rákóczi, Kossuth, and Petöfi. Keep calm and humanity now." The speaker knew that somehow he had disarmed one politically embarrassing detail of the biography of the poet, that in the Segesvár battle Petőfi died in the fight against the Russian soldiers invading Transylvania. Because of this, the speaker put the poet's death in a world-historical perspective and, as a solder reports to Petöfi: "We report instead of word with acts: the smashed German tyrant is lying on the ground. The freedom became an inalienable property of ten millions of Hungarians. The huts prevailed over the palaces. There is no more loved king, throne and crown (...) The Czar, who suppressed the Hungarian revolution, was trampled by his own people. And the Russian people freed from the tyrant destroyed and chased to the world our suppressors too and shared with our people his most precious blood over our treasure, the freedom. The red flag of the world freedom had triumphed in Europe and Asia."

Márton Horváth expressed also that "our most progressive poets of today already understood that consequently following Petöfi in the politics means socialism, and in the poetry the acquisition of the results of the Soviet literature."

The movie "The Sea is raised" by László Ranódy and Mihály Szemes, made in 1953, consistently implemented, visualized in a movie form, the state party Petöfi icon of the age. The famous Hungarian writer Gyula Illyés also cooperated in the making of the scenario of the film, but in the atmosphere saturated by politics the film became a real collective work: it was many times rewritten for the official instructions; moreover, the famous director of the classic Soviet battle movies, V. Pudovkin, was sent to Budapest. The film fulfilled the political expectations drawn up by the political system for "the revolutionary intelligentsia grown on the leadership". The leaders of the people, Petöfi, Kossuth were elected by the people, according to the demonstrative scenes of the film and since it did not disappoint, his election confirmed it with adoration again and again. During the scenes of the independence war a real revolutionary vanguard is shown: the Pole Bem, the Szekel Áron Gábor, the Romanian insurgents are fighting together for the revolution, and a fictional Russian hero protagonist, major Gusev, defected to the side of the Hungarian revolution.

György Konecsni created his picture Petöfi and Bem in 1952. Petöfi's popularity indicates that, between 1945 and 1956, many important institutions were named after him in this period. The most spectacular among these was the Sándor Petöfi Bridge, which is one of the great Danube bridges connecting Pest and Buda until today. The bridge was built in 1937 and was named after Miklós Horthy until 1945. 
During the siege of Budapest the bridge was blown up and was rebuilt for 1952, when it received its new name too. ${ }^{4}$

The Petöfi Literary Museum, established in Budapest in 1952, in its early years was dedicated to the works of four great Hungarian writers: Sándor Petőfi, Mór Jókai, Endre Ady, and Attila József. The predecessor of the museum was the Petöfi House, which was established by the initiative of the Petöfi Association in 1909. The institution, as its name implies, firstly was actually devoted to the works and writer personality of Sándor Petőfi, but soon extended its interest to the works of the prosaic Mór Jókai too. The establishment of the Petőfi House was obviously connected with the Petöfi cult in the Hungarian intellectual life of the second half of the 19th century. The original Petöfi House was bombed in 1945, and the collection had to move to another building after the war. The Károlyi Palace in Budapest became the final building of the museum where it is located today, in 1957.5

\section{THE POET'S EXPROPRIATION BY THE STATE-PARTY. THE RECENT FORMATION OF THE PETÖFI PICTURE}

The culture policy of the state party supported the gradual expansion of the official literary canon after 1956. Though clinging to Petöfi's cult, it also tried to sue back his heritage from the counter-revolutionaries, but removed his exclusivity. From the middle of the 1960s, our flag was Attila József.

The advantage of maintaining Petöfi's cult was that substantial sums had been spent on Petöfi research. Perhaps the most fruitful period of Petőfi research and literature were the years at the turn of the 1960s. In this period the biographical studies of Lajos Hatvany, András Dienes, Sándor Fekete were published, as well as the monographs on the epoch related to Petőfi by Pál Pándi and István Sőtér. But this cult also had a disadvantage, making the breakdown of the earlier, quite ideological picture difficult. For example, the wrongdoing was obvious in the case of the undeservedly neglected János Arany, and the urge for re-evaluation was even stronger.

This partly explains the fierce professional debates at the beginning of the 1970s on the knowledge of Petöfi on the French revolutions, the early socialists. The clarification attempts of Sándor Lukácsy, as Petőfi's revolution-perception was first of all related to the very radical ideas of Babeuf and Bounarroti, were regarded as an unfounded and distorting narrowing by Pál Pándi and Sándor Fekete. Béla Németh G.,

\footnotetext{
${ }^{4}$ www.budapest.com/budapest_kalauz/latnivalok/hidak/petofi-hid.hu.html

${ }^{5}$ http://www.pim.hu/object.ba860504-09f5-46cf-bd22-07bc440e7290.ivy
} 
Mihály Szegedy-Maszák and others tried reinterpreting the biography profile of Sándor Petöfi and, according to the age fashion, the first analysis volume was also written in the middle of the 1970s (Petöfi állomása, 1976). The editors of the new critical edition of Petőfi's poems, József Kiss and András Martinkó, accepted the blank points of the Petöfi research and Martinkó had serious arguments on the unreliability of the biographical chronology of the poet's life.

It is understandable that the literary interest lagged behind the scientific, as the value of the museum is a more important issue for the researchers. At the 150th anniversary of the poet's birth in 1973, many answered to the inquiry where Petöfi's place was in the present literary life; Sándor Weöres firmly stated that nowhere: "Petöfi is covered by his own statue, the previous pathetic, hand-raised-to-oath speaker today is an impecunious revolutionary." Sándor Csoóri referred to the tradition of the folk or people orientation writers saying that Petőfi did not become unseasonable, but we did.

When in a second-hand bookshop at the Museum Boulevard I bought the book of Márton Horváth (Lobogónk Petöfi. Irodalmi cikkek és tanulmányok. [Our flag, Petöfi. Literary studies], Szikra, Budapest, 1950) in 1972 or 1973, I wondered if the title of the book is a ridiculously foolish thought or a dangerous political program. At this time many tended to believe (I studied the contrary of this on my own hand that time) that the proletarian-dictatorship by Rákosi and Gerö was finally over. The newspapers, radio, and television parroted from dawn to dusk that while the socialism of comrade Kádár is the organic continuation the socialism before 1956, it is not similar. The Marxist philosophers were thinking for years if the socialism before and after 1956 are continuous or discontinuous. But one thing is sure, after 1956 Petőfi was not our flag.

The internationalist Petöfi and the communist world freedom were enthusiastically celebrated in front of the National Museum by the blue-shirted communist youth with red ties, deployed in disciplined lines on every 15 th March. Such celebrations of 15th March in front of the Budapest National Museum became a Bolshevik mass ceremony in the 1980s, with the slogans like: Long live Petöfi! Long live world freedom! Long live socialism.

But Petöfi remained an important symbol of the 1956 revolution as well. The revolutionary movement was first organized in the so called Petöfi Circle, where the Hungarian intelligentsia discussed the democratization of the Hungarian communist system. The emblematic poem of the Hungarian revolution, the poem "One sentence on the Tyranny" (Egy mondat a zsarnokságról) of Gyula Illyés was published in the Irodalmi Ujság (Literary Journal) on one of the last days of the revolution, 2nd November 1956, and then never more in Hungary until 1990. Symbolically, on the front 
page of this issue Petőfi's poem: “The Magyar became Magyar again...” (Ismét magyar lett a magyar... ) was published, corresponding tothe last happily feverish days of the Hungarian revolution.

It is an important coincidence that Gyula Illyés was that Hungarian writer, from the ranks of the so called people or folk writers, who wrote the new-minded monograph on the life of Sándor Petőfi. Illyés's monograph was published in the early 1960s, and then, enlarged and revised, in 1972. This book became the modern Petöfi's monograph, which determined the approach to Petöfi's picture of whole generations in the last decades of the Hungarian Communist era. Through the mediation of Gyula Illyés, Petőfi became the main persona of the Hungarian revolutionary, freedom seeking and national traditions.

\section{PETŐFl'S CULT AFTER 1989}

The Hungarian transition was a peaceful and gradual one, from the one-party dictatorship and planned economy system dominated by the state property to the pluralist democracy system and market economy based on free enterprise and private ownership. However, the most important event of the transition happened in 1989, including the renewal of the text of the old, Communist constitution, and in 1990, the first free parliamentary elections, while the whole process had already started in 1988.

The 1989-1990 Hungarian transition was basically a kind of a compromise and had begun earlier with the weakening of the communist regime and gradual internal reforms. At the same time, the elite nature of the opposition movements became more and more intense. The transition continued at the round-table discussions among the representatives of the state party and the opposition movements and then ended with the holding of the first free elections. However, the whole process was characterised with the pressure of the street demonstrations too, even though these were less intense than in many other Central European countries. This also partly corresponded with the long duration of the whole process. Still, the transition effectedrevolutionary changes on the economic-social and political side, which can also be characterized as the restoration of capitalism and political democracy.

The Hungarian political life is traditionally open to retrospection into the national past and, at the same time, to historicism. When the Hungarian political life has an option for it or if it is necessary, it likely reaches back to its historical roots, drawing strength and examples from the past. At the time of the 1989 transition, the updated references to the reform era (1832-1847) and the 1848 and 1849 revolution and Independence War also played an important role. The actors of these events became 
important again and the different reviving political movements wanted to see our own example of their personality and historical role, the "retrospective certification" of their transition policy.

Perhaps we can state with a slight exaggeration that the most popular examples of 1989 were not the radicals of the Hungarian past but the moderate liberals (the moderate progressive way of the Hungarian political history). This probably corresponded to the above-mentioned compromise-natured and peacefully negotiated method of the Hungarian transition, which was more similar to the Austro-Hungarian Compromise in 1867 than to the turbulent events of 1848 and 1849.

Maintaining the peaceful character was in the interest of both parties: the leaving power was already interested in a gradual and non-violent transition, and the coming powers were not potent enough, unique, and dedicated, because the public sentiment was not revolutionary. A large part of the population also hoped for a peaceful transition. The everyday social situation, in spite of the catastrophic economy figures and the moral crisis of the governmental power, was not catastrophic at all.

Therefore, in this historical situation and social milieu, the "considerately progressive”, earl István Széchényi seemed to be an example to follow, unlike Lajos Kossuth, who radicalized the events and seemed more populist. Because, for similar reasons, the youthfully rebellious tribune and democrat Sándor Petöfi was not expected to become a protagonist, but rather the moderate, compromise-seeking and conscious in legal forms moderate liberal Ferenc Deák, who was highly regarded for being the most important among the fathers of the 1867 compromise. Deák, who was widely liked among the representatives of the legal profession, also became the symbol of the considerate and sapient practicing politician.

These back-projected symbolical pictures were fixed in the Hungarian political public awareness of the 1990s for quite a long time. It is interesting that this perception was also expressed on the Hungarian banknotes. On those issued before the political transition, almost the whole Hungarian freedom fighting pantheon was represented (Petöfi on the 10 Forints banknote, György Dózsa on the 20 Forints banknote, Ferenc Rákóczi II: on the 50 Forints banknote, and finally Lajos Kossuth on the 100 Forints banknote). This was the thing of the past after the transition. The appearance of the Hungarian banknotes after the political transition moved in quite a monarchical direction. Because of this, Petőfi's picture also disappeared from the Hungarian banknotes, which were now in the ultraconservative Horthy period.

${ }^{6}$ The Hungarian citizens could meet higher denomination banknotes in the 1970s and 1980s, on which banknotes there were portraits not of politicians or generals but artists: the poet Endre Ady on the banknote with the denomination of 500 Forints and Béla Bartók on 1000 Forints. 
Petöfi's picture at first was posted on a Hungarian banknote, namely on the banknote denomination of 50 Pengö, in 1934, in the Horthy era. The final withdrawal of this banknote took place just in May 1946. The picture of Sándor Petőfi appeared on the banknote of 10 Forints from July 1947, which was withdrawn in September 1992, and its final limitation took place on 31 December 1993. Petőfi was not shown on any banknotes or coins after this point.

This "banishment of Sándor Petőfi" from the Hungarian banknotes did not mean that Petöfi's cult expired in Hungary after 1989 and 1990. Petőfi's poem National Song is still being studied, sooner or later, by all Hungarian schoolchildren or pre-schoolers during the preparations to the March celebrations. The institutions named after Petöfi before 1989 retained their names, among others the Petöfi Literary Museum, the Petőfi Bridge in Budapest, or the second program of the Hungarian public radio, which also existed before 1989, undertaking cultural public services as the Petöfi Radio. This program was changed in 2008 and became a cultural public service for the young generation with many modern and alternative music programs. ${ }^{7}$ Similar changes took place in the Hungarian Public Television in 2013 and 2014. The second program of the television (M2) was transformed into M2 Petöfi Television. The programs of this channel are intended mainly for children, but also attempt to address the younger generations. The Petöfi hannel mainly addresses the younger generation interested inthe music and cultural programs specifically after 8 p.m.

These and other name changes indicate that, in the post-millennium discourses and perhaps also in business marketing, Sándor Petöfi started to function as a symbol of youth, becoming mainly the symbol of the younger generation interested in the contemporary cultural life. Of course, he also retained the former symbolic meanings in the radical and liberal tradition. The surroundings of the Petőfi statue in Budapest, the 15th March Square, were the scene of the opposition demonstrations already before the political transformation, quite like the surroundings of Puskin statue in Moscow for the Russian opposition. The leadership of the local government of the Hungarian capital, Budapest, grew up from this opposition group and the Major of Budapest was the liberal politician, Gábor Demszky, so the 15th March Square and the surroundings of the Petőfi statue in Budapest gradually became the demonstration place of the local administration of the capital city and the Hungarian liberal political group between 1990 and 2010. This tradition survived after 2010, when the right political

${ }^{7}$ http://www.radio.hu/index.php?option=com_content\&task=blogcategory\&id=45\&Itemid=82, http:/hvg.hu/kultura/20080104_mr2_petofi_radio_zene 
turn also took place in the capital, but the decreasing numbers of liberal politicians further prefer to demonstrate near the Petöfi statue.

An interesting location for sharing demonstrations and celebrations in the last quarter of century In Budapest. The place of the central state celebration of the national holiday, the anniversary of the revolution and independency war of 1848 and 1849 is the park of the National Museum in Budapest. This tradition developed already in the old political system before the political transition. The other traditions were formed after 1990. The radical national and far-right movements prefer the Heroes Square in Budapest for demonstrations. The civic right-wing political groups use the places of Buda Castle for demonstrations, and sometimes the most important political place of the country, the Kossuth Square, in front of the building of the Parliament as well. It is interesting that the left-wing, socialist political group has no a traditional demonstration place in Budapest.

When the bill enabled the establishment of political parties from public funds party foundations, which are functioning as intellectual think tanks of political groups, none selected the name of Sándor Petöfi. The Socialist Party chose the name of Mihály Táncsics, who was to the left from Petöfi in 1848 and 1849, but the liberals, the greens and the nationals also chose other names.

The symbol of Sándor Petöfi has later been functioning as the symbol of the freedom of the press. The Community of Hungarian Journalists (Magyar Újságírók Közössége) awards the deserving journalists with the Prize of Sándor Petöfi Freedom of the Press. This prize was established in 2010, mainly for right-wing journalists. The Central and Eastern European History and Society Public Foundation established the Sándor Petöfi Prize in 2009. The Foundation awards this prize not just to Hungarian, but also Central European personalities; in 2012 it was awarded to the famous Slovak liberal politician, Miroslav Kusý, for his humanist position towards the Hungarian minority group in Slovakia. These prizes indicate that the heritage of Sándor Petöfi is an important symbol also for the national and civic right-wing political groups, which is an important evidence for the manifold cult of Sándor Petöfi. 


\section{THE STATUE OF SÁNDOR PETŐFI IN BUDAPEST AND ITS SYMBOLIC IMPORTANCE}

The first public square sculpture for Sándor Petőfi in Budapest was inaugurated on 15 th October 1882. Before the inauguration of this statue a long preparatory process took place, because the idea of the statue was born already in the 1960s. The committee for the building of the statue was officially established in August 1867, after the ratification of the Austro-Hungarian Compromise. ${ }^{8}$ Several possible sites in Budapest were imagined for the statue, and finally the monument got to the Pest bank of the Danube, where it has remained ever since. The name of the square lying around the statue is the 15th March Square.

\section{TRANSLATION: AndOr MESZAROS}

8 Soós Gyula's view of this process: Conditions to erect a Petőfi statue in Budapest. http://epa.oszk.hu/02100/02120/00011/pdf/ORSZ_BPTM_TBM_11_335.pdf

\section{BIBLIOGRAPHY:}

Gyüia Soós, A budapesti Petőfi-szobor felállításának körülményei, [strona WWW]: : http://epa.oszk. $\mathrm{hu} / 02100 / 02120 / 00011 / \mathrm{pdf} / \mathrm{ORSZ}$ _BPTM_TBM_11_335.pdf [dostęp: 16-04-01] [strona WWW]: http://hvg.hu/kultura/20080104_mr2_petofi_radio_zene [dostęp: 16-04-01]

[strona WWW]: http://www.radio.hu/index.php?option=com_content\&task=blogcategory\&id=45\&Itemid=82, [dostęp: 16-04-01]

[strona WWW]: http://www.pim.hu/object.ba860504-09f5-46cf-bd22-07bc440e7290.ivy [dostęp: 16-04-01]

[strona WWW]: http://www.budapest.com/budapest_kalauz/latnivalok/hidak/petofi-hid.hu.html [dostęp: 16-04-01] 